\section{Soviet Scientific Films}

A MYCRO-CINEMATOGRAPHIC study of the human capillaries is to be made by the medical cinematographic department of the Soviet Commissariat of Health. According to Mr. Volkof, the head of the department, the chief advantages of the scientific medical film in medicine lies in the possibility it opens up of modifying the time range of experiments to meet requirements. Action can be accelerated or slowed down at will. Moreover, the photomicrograph flashed on the screen frequently discloses many details unseen to the eye even with the aid of the microscope.

\section{The Influenza Epidemic}

THE Minister of Health has had special inquiries made through the regional medical officers of the Ministry into the local prevalence of the influenza epidemic. It appears that generally there is at present an extension from south to north, but that the distribution is patchy. Prevailing medical opinion is that the present outbreak, though widespread and highly infectious, is for the most part mild, most of the deaths being among the elderly. In the week ending January 9, there were 768 deaths ascribed to influenza in 122 great towns, as compared with 325 for the previous week, and the number of notifications of primary and influenzal pneumonia increased from 1,513 to 2,321 .

\section{The Night Sky in February}

Between February I and February 28, the length of the night in the latitude of London decreases from $14^{\mathrm{h}} 54^{\mathrm{m}}$ to $13^{\mathrm{h}} 13^{\mathrm{m}}$. New moon occurs on February $11^{\mathrm{d}} 7 \cdot 6^{\mathrm{h}}$ and full moon on February $25^{\mathrm{d}} 7 \cdot 7^{\mathrm{h}}$. The planet Venus in the evening sky is a brilliant object ; and in conjunction with the crescent moon on February $14^{\mathrm{d}} 23^{\mathrm{h}}$ will make a striking spectacle. On February 15 at $23^{\mathrm{h}}$, the planet will pass within $3^{\prime}$ of the star $\delta$ Piscium (magnitude $4 \cdot 6$ ). Venus is at greatest elongation $\left(47^{\circ}\right.$ E.) on February 5. Mercury is a morning star at greatest western elongation $\left(26^{\circ}\right)$ on February 7 , when it rises about $1^{\mathrm{h}} 12^{\mathrm{m}}$ before the sun. On February 9 at $7^{\text {h }}$, Mercury is in conjunction with the moon, the planet being $2^{\circ}$ south of the latter. In mid-February, Saturn sets about two hours after the sun. On February 20, the plane of the rings passes through the earth, and the appearance of the ring system in large telescopes will be of special interest. In 1920 and 1921 when the system could be viewed in similar circumstances as will occur on February 20, it was found that the rings did not completely disappear--a fact which has a bearing on their thickness and structure. On February 13 at $15^{\mathrm{h}}$, Saturn will be in conjunction with the moon, the planet being $8^{\circ} \mathrm{S}$. Jupiter rises near daybreak in the south-east; its magnitude is $-1 \cdot 5$. The most favourable times for observing the light changes of Algol (R.A. $3^{\mathrm{h}} 04^{\mathrm{m}}$, Dec. $40^{\circ}$ $43^{\prime}$ N.) are as follows : February $2^{\mathrm{d}} 2 \cdot 4^{\mathrm{h}}, 4^{\mathrm{d}} 23 \cdot 2^{\mathrm{h}}$, $7^{\mathrm{d}} 20 \cdot 0^{\mathrm{h}}, 22^{\mathrm{d}} 4 \cdot 1^{\mathrm{h}}, 25^{\mathrm{d}} 0 \cdot 9^{\mathrm{h}}$ and $27^{\mathrm{d}} 21 \cdot 8^{\mathrm{h}}$. The radiant for the $\alpha$ Leonid meteors on February 22-28 is at R.A. $10 \cdot 4^{\mathrm{h}}$, Dec. $14^{\circ} \mathrm{N}$.

\section{Announcements}

The French Government has awarded the rank of Chevalier of the Legion of Honour to Prof. J. B. S. Haldane, professor of genetics, University College, London, for his scientific services to France.

Prof. Arthur Holmes, professor of geology in the Durham Division of the University of Durham, has been elected a foreign correspondent of the Geological Society of America.

The John Anisfield Award has been given to Drs. Julian Huxley and A. C. Haddon for their book "We Europeans: A Survey of 'Racial' Problems", with a chapter on "Europe Overseas" by Prof. A. M. Carr-Saunders, which was reviewed in NATURE of November 9,1935 , p. 736 . The judges of the award are Prof. Henry Pratt Fairchild of the University of New York, Prof. Donald Young of the Social Science Research Council, and H. S. Canby of the Saturday Review. The prize is given for "a sound and significant book published in the previous twelve months on the subject of racial relations in the contemporary world".

Ar the annual meeting of the New York Academy of Sciences held on December 21, the following honorary members were elected : Prof. K. S. Lashley, of Harvard University ; Prof. Henri Breuil, professor of prehistory in the Collège de France; Dr. Julian S. Huxley, secretary of the Zoological Society of London; Dr. Aleš Hrdlička, curator of physical anthropology in the U.S. National Museum; Dr. A. C. Haddon, formerly reader in ethnology in the University of Cambridge; Sir Arthur Hill, director of the Royal Botanic Gardens, Kew ; Prof. Maurice Caullery, professor of zoology (evolution) at the Sorbonne, and Prof. Octave Duboscq, professor of marine biology at the Sorbonne.

LORD NUFFIELD has given a silver trophy which will be awarded to the town or village collecting the most money, per head of population, for the annual Empire Day appeal for the British Empire Cancer Campaign. In 1931 Lord Nuffield gave $£ 25,000$ to the British Empire Cancer Campaign to be invested to provide a research fellowship at the Mount Vernon Hospital.

AT the annual meeting of the Royal Meteorological Society, held on January 20, the following officers were elected: President, Dr. F. J. W. Whipple; Treasurer, W. M. Witchell; Secretaries, H. W. L. Absalom, W. Dunbar and E. L. Hawke; Foreign Secretary, J. F. Shipley; New Members of Council, Miss Elen E. Austin and R. S. Read.

A PRIZE of $£ 20$ with a diploma is awarded annually by the Royal Asiatic Society for an essay on a selected subject. The object of the competition is to encourage interest in the history and civilization of the East among non-Asiatics. Alternative subjects for 1937 are: $(a)$ "Tamerlane" and (b) The Relations of the Greeks with the East". Essays must be in the hands of the secretary by October 1. Further information can be obtained from the Secretary, Royal Asiatic Society, 74 Grosvenor Street, London, W.1. 